\title{
PENGETAHUAN MASYARAKAT TENTANG COVID-19 BERHUBUNGAN DENGAN KEPATUHAN MENGGUNAKAN MASKER PADA MASA PANDEMI COVID-19
}

\author{
Caroline Virgine Putri Lesilolo \\ Fakultas Kedokteran, Universitas Lampung, Jl. Prof. DR. Ir. Sumatri Brojonegoro No.1, Gedong Meneng, \\ Kec. Rajabasa, Kota Bandar Lampung, Lampung, Indonesia 35145 \\ vplcarol@gmail.com (+6282114056009)
}

\begin{abstract}
ABSTRAK
Covid-19 merupakan suatu penyakit menular yang menyerang saluran pernapasan. Sejak kasus pertama ditemukan pada Desember 2019, angka kematian akibat Covid-19 terus meningkat. Sumber utama penularan virus ini adalah melalui percikan cairan ketika individu yang terpapar Covid-19 batuk, bersin, teriak, bernyanyi ataupun berbicara. Maka dari itu penggunaan masker merupakan cara pencegahan penularan yang sangat efektif karna dapat menahan percikan yang keluar agar tidak menulari individu lainnya, tetapi faktanya didapatkan banyak masyarakat yang belum patuh menerapkan perilaku tersebut. Banyak faktor yang memengaruhi kepatuhan, seperti pengetahuan. Didasari oleh rendahnya kepatuhan masyarakat dan pentingnya penggunaan masker guna mencegah penularan Covid-19 yang dapat mengakibatkan kematian, maka artikel ini dibuat untuk membahas hubungan pengetahuan tentang Covid-19 terhadap kepatuhan dalam menggunakan masker selama pandemi Covid-19. Metode yang digunakan adalah metode literature review melalui penelusuran menggunakan database Google Scholar dan PubMed, diseleksi dan diperoleh hasil akhir 19 artikel dari PubMed dan 10 artikel dari Google Scholar yang kemudian dianalisis berdasarkan metode sistematik literature review. Dari penelitian yang telah dilakukan, didapatkan hasil yang kuat bahwa terdapat hubungan yang signifikan antara pengetahuan masyarakat tentang Covid-19 terhadap kepatuhan menggunakan masker pada masa pandemi Covid-19.
\end{abstract}

Kata kunci: covid-19; kepatuhan; pengetahuan; penggunaan masker

\section{PUBLIC KNOWLEDGE ABOUT COVID-19 RELATED TO COMPLIANCE OF USING MASKS DURING THE COVID-19 PANDEMIC}

\begin{abstract}
Covid-19 is an infectious disease that attacks the respiratory tract. Since the first case was discovered in December 2019, the death toll from Covid-19 has continued to rise. The main source of transmission of this virus is through liquid splashes when individuals exposed to Covid-19 cough, sneeze, shout, sing or talk. Therefore the use of masks is a very effective way of preventing transmission because it can withstand the splashes that come out so as not to infect other individuals, but the fact is that there are still many people who have not complied with this behavior. Many factors affect compliance, such as knowledge. Based on the low level of community compliance and the importance of using masks to prevent the transmission of Covid19 which can result in death, this article was created to discuss the relationship between knowledge about Covid-19 and adherence to wearing masks during the Covid-19 pandemic. The method used is the literature review method through a search using the Google Scholar and PubMed databases, selected and the final results obtained are 19 articles from PubMed and 10
\end{abstract}


articles from Google Scholar which are then analyzed based on a systematic literature review method. From the research that has been done, there are strong results that there is a significant relationship between public knowledge about Covid-19 and adherence to using masks during the Covid-19 pandemic.

Keywords: compliance; covid-19; knowledge; use of masks

\section{PENDAHULUAN}

Coronavirus 2019 atau yang selanjutnya dikenal dengan istilah Covid-19, merupakan suatu penyakit menular yang saat ini menjadi perhatian dunia. Disebabkan oleh strain coronavirus Severe Acute Respiratory Syndrome Coronavirus 2 (SARS-CoV-2) dengan kasus pertama ditemukan di Wuhan, Cina pada Desember 2019 (Wiersinga et al., 2020).

Covid-19 telah dideklarasikan sebagai pandemi global terhitung sejak tanggal 11 Maret 2020 oleh World Health Organization (WHO). Artinya, Covid19 tersebar secara luas di dunia dengan lebih dari 80.000 kasus yang dikonfirmasi telah dilaporkan di seluruh dunia per 28 Februari 2020 dan masih terus bertambah dibuktikan dengan grafik jumlah kasus terkonfirmasi dan meninggal terus meningkat hingga saat ini (Cucinotta \& Vanelli, 2020). Berdasarkan data dari Kementerian Kesehatan RI, di Indonesia sendiri terdapat 2.345.018 kasus terkonfirmasi positif dan 61.868 kasus meninggal per 6 Juli 2021.

Penyebaran SARS-CoV-2 dari manusia ke manusia menjadi sumber penularan utama sekaligus faktor yang menjadi alasan cepatnya transmisi Covid-19 dimana penularan melalui droplet yakni percikan cairan yang keluar ketika individu yang terpapar Covid-19 batuk, bersin, teriak, bernyanyi ataupun berbicara. Selanjutnya didapatkan bukti kuat dan konsisten bahwa SARS-CoV-2 menyebar melalui transmisi udara (airborne transmission) dan dalam percobaan laboratorium, SARS-CoV-2 terdeteksi di udara serta dapat tetap menular hingga 3 jam di udara dengan waktu paruh $1 \bullet 1$ jam (Greenhalgh et al., 2021).

Dilihat dari cara penularan SARS-CoV2, dapat kita pikirkan bahwa lingkungan dengan tingkat kepadatan penduduk tinggi serta mobilitas yang tinggi berbanding lurus dengan tingginya risiko penularan serta penyebaran virus ini. WHO telah mengajak pemerintah dan masyarakat seluruh negara terdampak wabah Covid-19 untuk sama-sama melakukan langkah efektif dalam upaya pencegahan penyebaran dalam rangka memutus rantai penularan Covid-19 (Mushidah \& Muliawati, 2021). Dalam rangka pengendalian penyebaran Covid-19 yang mana merupakan penyakit yang menyerang saluran pernapasan, dibutuhkan suatu upaya komprehensif untuk mencegah penularan lebih lanjut yaitu dengan menggunakan masker secara baik dan benar (Hutagaol \& Wulandari, 2021). Di Indonesia sendiri, pemerintah melalui gerakan "Semua Pakai Masker" telah mewajibkan penggunaan masker oleh semua orang ketika berada diluar rumah yang ditetapkan dalam Keputusan Presiden Nomor 11 Tahun 2020 sesuai dengan ketentuan peraturan perundang-undangan. Namun fakta di lapangan didapatkan banyak masyarakat yang belum patuh menerapkan perilaku tersebut walaupun telah diberlakukan sanksi material. Salah satu alasan ketidakpatuhan tersebut dikarenakan masyarakat menganggap protokol 
kesehatan mengganggu kehidupan sosial mereka (Indrayathi et al., 2021).

Permasalahan tersebut muncul di masyarakat disebabkan banyak faktor yang memengaruhi kepatuhan seseorang diantaranya pengetahuan, motivasi, persepsi, ataupun keyakinan dalam mengontrol dan mencegah berbagai kondisi, variabel, kemampuan akses sumber yang ditemukan di lingkungan, dan kualitas dari bidang kesehatan (Sinuraya et al., 2018). Didasari oleh rendahnya kepatuhan masyarakat di Indonesia menerapkan perilaku pencegahan Covid-19, terbatasnya pengetahuan yang beredar di masyarakat tentang Covid-19, serta minimnya kesadaran untuk menggunakan masker ketika berada diluar rumah maka artikel ini akan membahas hubungan faktor pengetahuan masyarakat mengenai Covid-19 terhadap kepatuhan masyarakat tersebut dalam menggunakan masker pada masa pandemi Covid-19.

\section{METODE}

Metode yang digunakan dalam penyusunan penulisan ini adalah metode literature review, melalui penelusuran menggunakan mesin pencarian online dari database Google Scholar dan PubMed serta beberapa literatur dari organisasi perkumpulan kesehatan dunia seperti WHO. Kata kunci yang digunakan adalah 'Covid19, compliance, kepatuhan, knowledge, pengetahuan, penggunaan masker, dan use of masks'. Hasil yang ditemukan dari pencarian literatur adalah 33 pustaka dari PubMed dan 419 pustaka dari Google Scholar. Kemudian, jurnal tersebut diseleksi dan diperoleh hasil akhir 19 artikel dari PubMed dan 10 artikel dari Google Scholar yang memenuhi kriteria berdasarkan rentang publikasi yaitu tahun 2016-2021, judul, hasil, dan pembahasan yang membahas tentang hubungan pengetahuan tentang Covid-19 terhadap kepatuhan menggunakan masker pada masa pandemi, selain itu artikel dipilih jika tersedia dalam free full text. Artikel yang telah diseleksi kemudian dianalisis berdasarkan metode sistematik literature review dengan mengidentifikasi, menilai, dan menginterpretasikan temuan penelitian sebagai bahan yang dibutuhkan dalam penulisan artikel dengan merangkum hasil penelitian.

\section{HASIL}

Berdasarkan penelitian oleh Mushidah \& Muliawati (Mushidah \& Muliawati, 2021) tentang pengetahuan serta sikap dengan kepatuhan menggunakan masker pada pedagang UMKM, menggunakan metode observasional analitik dengan pendekatan Cross Sectional kepada 52 sampel responden yang didominasi memiliki tingkat pengetahuan yang kurang terhadap Covid-19 (55,8\%), didapatkan hasil berupa sebagian besar responden, yaitu sebanyak $75,9 \%$, tidak patuh terhadap aturan menggunakan masker dan hanya sebanyak $30,4 \%$ yang patuh terhadap aturan menggunakan masker. Hasil analisis ini menggunakan uji alternative Fisher's Exact Test, didapatkan nilai $p$ value $=0,000(p<0,05)$, maka interpretasi dari nilai tersebut menunjukkan bahwa terdapat hubungan antara tingkat pengetahuan Covid-19 terhadap kepatuhan menggunakan masker.

Sejalan dengan penelitian dari Dwi Susilowati (Susilowati et al., 2020) tentang hubungan pengetahuan dan peran petugas kesehatan dengan kepatuhan menggunakan masker, menggunakan survei analitik Cross Sectional kepada 95 responden yang 
didominasi oleh responden tamatan Sekolah Mengengah Pertama dan tidak bekerja, didapatkan hasil yaitu 59,3\% responden dengan pengetahuan kurang cenderung tidak patuh menggunakan masker; 35,3\% responden dengan pengetahuan cukup tidak patuh menggunakan masker dan persentase patuh yaitu $64,7 \%$; $86,3 \%$ responden dengan pengetahun baik cenderung patuh menggunakan masker. Hasil analisis dengan menggunakan uji chi square didapatkan nilai $p$-value $=0,000$ $(p<0,05)$, maka interpretasi dari nilai tersebut menunjukkan bahwa terdapat hubungan pengetahuan dengan kepatuhan menggunakan masker.

Hasil yang sama juga didapatkan dari penelitian oleh Hutagaol dan Wulandari (Hutagaol \& Wulandari, 2021) tentang hubungan pengetahuan remaja dengan kepatuhan menggunakan masker, menggunakan metode survei analitik kepada 55 responden, dimana berdasarkan survei yang dilakukan diketahui tingkat pengetahuan responden tentang Covid-19 sebagian besar adalah baik dengan persentase sebanyak 65,5\%. Hasil penelitian tersebut didapatkan sebanyak 94,55\% responden patuh dalam menggunakan masker, dan 5,45\% responden tidak patuh dalam menggunakan masker. Hasil analisis penelitian ini menggunakan uji chi squre didapatkan nilai $p$-value $=0,020 \quad(p<0,05)$, maka interpretasi nilai tersebut menunjukkan bahwa terdapat hubungan tingkat pengetahuan dengan kepatuhan menggunakan masker.

\section{PEMBAHASAN}

Pengetahuan merupakan salah satu faktor terpenting yang dapat memengaruhi kepatuhan seseorang disamping faktor lainnya yaitu motivasi, persepsi, ataupun keyakinan dalam mengontrol dan mencegah berbagai kondisi, variabel, kemampuan akses sumber yang ditemukan di lingkungan, dan kualitas dari bidang kesehatan. Kepatuhan dapat diartikan sebagai suatu istilah yang digunakan untuk mencerminkan perilaku individu dalam mematuhi suatu rencana atau anjuran tertentu. Sedangkan pengetahuan itu sendiri dapat didefinisikan sebagai segala sesuatu yang merupakan hasil dari tahu melalui penginderaan oleh setiap individu terhadap suatu objek (Anggreni \& Safitri, 2020).

Pengetahuan yang baik dan benar tentang Covid-19 merupakan hal yang pokok dan utama yang harus dimiliki oleh tiap individu (masyarakat) guna memutus rantai penyebaran Covid-19 (Saputra \& Simbolon, 2020) dikarenakan pengetahuan dapat memengaruhi tindakan individu, maka dari itu semakin baik pengetahuan individu terhadap suatu hal, dalam hal ini yang dimaksud adalah pengetahuan tentang Covid-19, semakin baik pula tindakan pencegahan yang dilakukan. Pengetahuan tiap individu memiliki berbagai faktor baik faktor internal seperti tingkat pendidikan individu tersebut, usia individu, minat tiap individu, pekerjaan, maupun faktor eksternal seperti lingkungan sekitar individu, informasi yang diperoleh tiap individu, serta pengalaman atau kejadian yang pernah dialami individu (Nuriati et al., 2021). Pengalaman tiap individu dapat diperoleh dengan proses belajar baik formal maupun informal, salah satunya bersekolah ataupun bekerja, semakin lama atau sering seseorang bersekolah ataupun bekerja, pengalaman yang didapatkan akan semakin banyak pula, dan ini berperan besar terhadap pengetahuan serta dapat membentuk perilaku individu tersebut. Faktor eksternal lainnya yaitu 
berhubungan dengan akses informasi yang dapat diperoleh, dimana semakin tinggi tingkat pendidikan suatu individu kemungkinan mendapatkan akses ke berbagai informasi semakin luas (Yanti et al., 2020). Selain tingkat pendidikan, guna dapat menyediakan fasilitas untuk mendapatkan informasi yang beragam, luas, serta benar, status sosial ekonomi seseorang dapat berperan besar akan pengetahuan yang dimiliki seseorang. Faktor eksternal lainnya menurut Nuriati yaitu lingkungan sekitar individu. Lingkungan yang dimaksud mencakup lingkungan fisik, biologis, dan sosial. Lingkungan menjadi faktor yang cukup berpengaruh dikarenakan pada suatu lingkungan pasti didalamnya terdapat suatu interaksi sesama individu yang akan berperan terhadap masuknya berbagai informasi yang akan membetuk pengetahuan individu yang berada di lingkungan tersebut (Syafel \& Fatimah, 2020).

Tingkat pendidikan individu berbanding lurus dan secara signifikan memiliki hubungan dengan tingkat kepatuhan individu tersebut. Hal ini selaras dengan hasil penelitian Mushidah \& Muliawati (Mushidah \& Muliawati, 2021) terkait hubungan pengetahuan serta sikap dengan kepatuhan memakai masker kepada 52 pedagang UMKM di Desa Kutoharjo Kaliwungu, dengan $p$ value $=0,000(<0,050)$, didapatkan hasil yang selaras dimana sebagian besar responden tidak mendapatkan pendidikan yang tinggi yang mana memengaruhi tingkat pengetahuan responden yaitu sebagian besar memiliki pengetahuan yang kurang terhadap Covid-19 dan pada akhirnya tingkat kepatuhan penggunaan masker pun rendah, dimana diketahui bahwa pengetahuan merupakan dasar untuk menentukan perilaku individu (Sari \& Atiqoh, 2020).
Penelitian lainnya yang sejalan dengan penelitian sebelumnya yaitu menurut Ika Purnamasari dalam jurnal tingkat pengetahuan dan perilaku masyarakat tentang Covid-19 (Purnamasari \& Ell Raharyani, 2020), dikatakan melalui proses menimba ilmu, pengetahuan yang merupakan faktor mendasar yang memengaruhi perilaku seseorang dapat menjadi lebih baik. Hasil penelitian tersebut juga sejalan dengan penelitian tentang hubungan pengetahuan dengan kepatuhan menggunakan masker kepada 55 remaja di SMA Perguruan Advent Salemba (Hutagaol \& Wulandari, 2021), dengan $p$-value $=0,020 \quad(<0,050)$ yang menunjukkan hubungan spesifik tingkat pengetahuan dengan kepatuhan menggunakan masker. Sebagian besar responden, yang merupakan remaja yang masih menimba ilmu di bangku Sekolah Menengah Atas, memiliki tingkat pengetahuan yang tinggi tentang Covid-19 sehingga didapatkan juga tingkat kepatuhan pemakaian masker yang tinggi berdasarkan hasil survei.

Berdasarkan penelitian Dwi Susilowati (Tabel 2) tentang hubungan pengetahuan dengan kepatuhan menggunakan masker kepada 95 masyarakat di Desa Jelapat 1 Kabupaten Batola, dengan $p$-value $=0,000(<0,050)$, dimana disimpulkan bahwa terdapat hubungan yang bermakna antara pengetahuan dengan kepatuhan menggunakan masker, hal ini dapat ditunjukkan dari sebagian besar responden menempuh pendidikan hanya sampai jenjang Sekolah Menengah, sebagian responden tidak memiliki pekerjaan, dan selaras dengan tingkat pengetahuan tentang Covid-19 yang kurang, dimana individu yang memiliki pengetahuan kurang cenderung tidak mematuhi aturan penggunaan masker dibandingkan individu yang memiliki 
tingkat pengetahuan tentang Covid-19 yang baik yang cenderung mematuhi aturan penggunaan masker (Purnamasari \& Ell Raharyani, 2020). Penelitian ini sejalan dengan penelitian oleh Mushidah \& Muliawati (2021), Hutagaol \& Wulandari (2021), dan Ika Purnamasari (2020), dimana didapatkan hubungan yang signifikan antara pengetahuan seseorang tentang Covid19 terhadap kepatuhan menggunakan masker.

Kepatuhan seseorang terhadap suatu hal dipengaruhi oleh pengetahuan, motivasi, persepsi, ataupun keinginan (Anggreni \& Safitri, 2020), dimana tanpa dimulai dengan rasa keingintahuan dan kepedulian, kepatuhan tidak dapat tercapai. Berdasarkan penelitian oleh Raynell Lang dkk terkait sikap dan perilaku terhadap tindakan pencegahan Covid19, didapatkan bahwa masyarakat dengan kepedulian terkait Covid-19 yang lebih rendah menunjukkan penyerapan informasi paling sedikit dari tindakan kesehatan masyarakat guna mencegah penyebaran Covid-19, salah satunya adalah penggunaan masker (Lang et al., 2021).

Pemerintah berupaya meningkatkan sumber serta banyaknya informasi terkait pengetahuan Covid-19 dalam rangka mencegah penyebaran virus dengan mematuhi protokol kesehatan seperti memakai masker saat diluar rumah atau pada saat menjaga orang satu rumah yang sedang sakit, mencuci tangan menggunakan sabun dan air mengalir, menjaga jarak minimal 1-2 meter, menjauhi kerumunan, seta mengurangi mobiitas. Pengetahuan terkait Covid-19 ini dibagikan melalui situs resmi di berbagai media, yaitu media sosial, radio, televisi, poster, flyer, baliho, papan reklame, himgga televisi layar lebar (Susilowati, 2016).

Berdasarkan penelitian yang telah dilakukan, didapatkan hasil yang kuat bahwa terdapat hubungan antara pengetahuan masyarakat tentang Covid19 terhadap kepatuhan masyarakat tersebut dalam menggunakan masker pada masa pandemi Covid-19.

\section{SIMPULAN}

Pandemi Covid-19 mengakibatkan berbagai perubahan global secara besarbesaran hampir dua tahun belakangan ini. Upaya penanggulangan virus penyebab Covid-19 ditujukan dengan mematuhi segala protokol kesehatan termasuk penggunaan masker. Diketahui terdapat berbagai faktor yang dapat memengaruhi kepatuhan seseorang menggunakan masker, seperti pengetahuan, motivasi, persepsi, dan keyakinan tentang Covid-19. Pengetahuan sendiri memiliki banyak faktor baik internal maupun eksternal, seperti tingkat pendidikan, usia, minat, pengalaman, serta lingkungan sekitar individu. Berdasarkan berbagai penelitian, didapatkan hubungan yang bermakna terkait pengetahuan masyarakat tentang Covid-19 dengan kepatuhan menggunakan masker. Penelitian menunjukkan masyarakat dengan tingkat pengetahuan tentang Covid-19 yang baik cenderung patuh untuk menggunakan masker, sedangkan masyarakat dengan tingkat pengetahuan Covid-19 yang kurang cenderung tidak patuh untuk menggunakan masker pada masa pandemi Covid-19.

\section{DAFTAR PUSTAKA}

Anggreni, D., \& Safitri, C. A. (2020). Hubungan Pengetahuan Remaja tentang COVID-19 dengan Kepatuhan dalam Menerapkan Protokol Kesehatan di Masa New 
Normal. Hospital Majapahit, 12(2), 134-142.

Cucinotta, D., \& Vanelli, M. (2020). WHO declares COVID-19 a pandemic. Acta Biomedica, 91(1), 157-160.

https://doi.org/10.23750/abm.v91i 1.9397

Greenhalgh, T., Jimenez, J. L., Prather, K. A., Tufekci, Z., Fisman, D., \& Schooley, R. (2021). Ten scientific reasons in support of airborne transmission of SARSCoV-2. The Lancet, 397(10285), 1603-1605.

https://doi.org/10.1016/S01406736(21)00869-2

Hutagaol, G. R. N., \& Wulandari, I. S. M. (2021). Hubungan Pengetahuan Remaja dengan Kepatuhan Penggunaan Masker Dalam Upaya Pencegahan Covid19 di SMA Perguruan Advent Salemba. Chmk Nursing Scientific Journal, 5(2), 66-72. http://cyberchmk.net/ojs/index.php/ners/articl e/view/981

Indrayathi, P. A., Januraga, P. P., Pradnyani, P. E., Gesesew, H. A., \& Ward, P. R. (2021). Perceived Social Norms as Determinants of Adherence to Public Health Measures Related to COVID-19 in Bali, Indonesia. Frontiers in Public Health, 9(April). https://doi.org/10.3389/fpubh.202 1.646764

Lang, R., Benham, J. L., Atabati, O., Hollis, A., Tombe, T., Shaffer, B., Burns, K. K., MacKean, G., Léveillé, T., McCormack, B., Sheikh, H., Fullerton, M. M., Tang, T., Boucher, J. C., Constantinescu, C., Mourali, M., Manns, B. J., Marshall, D. A., Hu, J., \& Oxoby, R. J. (2021).
Attitudes, behaviours and barriers to public health measures for COVID-19: a survey to inform public health messaging. $B M C$ Public Health, 21(1), 1-15. https://doi.org/10.1186/s12889021-10790-0

Mushidah, \& Muliawati, R. (2021). Pengetahuan dan Sikap dengan Kepatuhan Penggunaan Masker Sebagai Upaya Pencegahan Penyebaran Covid-19 Pada Pedagang UMKM. Jurnal Ilmiah Permas: Jurnal Ilmiah STIKES Kendal, 11(1), 35-42.

Nuriati, Y., Heryana, A., Mustikawati, I. S., Sangadji, N. W., Studi, P., Masyarakat, K., Kesehatan, F. I., \& Unggul, U. E. (2021). Persepsi Karyawan terhadap Ketersediaan Fasilitas dan Sarana Penanganan COVID-19 di Tempat Kerja Berhubungan dengan Kepatuhan. Jurnal Kesehatan Masyarakat, 9(4), 566-575. http://ejournal3.undip.ac.id/index. $\mathrm{php} / \mathrm{jkm}$

Purnamasari, I., \& Ell Raharyani, A. (2020). Tingkat Pengetahuan Dan Perilaku Masyarakat Kabupaten Wonosobo Tentang Covid -19. Living Islam: Journal of Islamic Discourses, 3(1), 125.

Saputra, A. W., \& Simbolon, I. (2020). Hubungan Tingkat Pengetahuan tentang COVID-19 terhadap Kepatuhan Program Lockdown untuk Mengurangi Penyebaran COVID-19 di Kalangan Mahasiswa Berasrama Universitas Advent Indonesia. Nutrix Jurnal, 4(No. 2), 1-7.

Sari, D. P., \& Atiqoh, N. S. (2020). Hubungan Antara Pengetahuan Masyarakat Dengan Kepatuhan Penggunaan Masker Sebagai 
Upaya Pencegahan Penyakit Covid-19 Di Ngronggah. Infokes: Jurnal Ilmiah Rekam Medis Dan Informatika Kesehatan, 10(1), 5255.

https://doi.org/10.47701/infokes.v $10 \mathrm{i} 1.850$

Sinuraya, R. K., Destiani, D. P., Puspitasari, I. M., \& Diantini, A. (2018). Medication Adherence among Hypertensive Patients in Primary Healthcare in Bandung City. Indonesian Journal of Clinical Pharmacy, 7(2), 124133.

https://doi.org/10.15416/ijcp.2018 .7.2.124

Susilowati, D. (2016). Promosi Kesehatan: Modul Bahan Ajar Cetak Keperawatan. Pusdik SDM Kesehatan Kemenkes RI. Jakarta: Kementerian Kesehatan Republik Indonesia

Susilowati, D., Indah, M. F., \& Agustina, N. (2020). Hubungan Pengetahuan dan Peran Petugas Kesehatan dengan Kepatuhan Menggunakan Masker dalam Upaya Pencehagan Covid-19 di Desa Jelapat 1 Kabupaten Batola [Universitas Islam Kalimantan MAB]. http://eprints.uniskabjm.ac.id/id/eprint/3921
Syafel, A. B., \& Fatimah, A. (2020). Hubungan Pengetahuan, Sikap Dan Perilaku Dengan Kepatuhan Ibu Rumah Tangga Dalam Pencegahan Covid-19 Di Rt 02 Rw 05 Kabandungan I Desa Sirnagalih Bogor. Pkm-P, 4(1), 112. https://doi.org/10.32832/pkmp.v4i1.728

Wiersinga, W. J., Rhodes, A., Cheng, A. C., Peacock, S. J., \& Prescott, H. C. (2020). Pathophysiology, Transmission, Diagnosis, and Treatment of Coronavirus Disease 2019 (COVID-19): A Review. JAMA - Journal of the American Medical Association, 324(8), 782793.

https://doi.org/10.1001/jama.2020 .12839

Yanti, B., Wahyudi, E., Wahiduddin, W., Novika, R. G. H., Arina, Y. M. D., Martani, N. S., \& Nawan, N. (2020). Community Knowledge, Attitudes, and Behavior Towards Social Distancing Policy As Prevention Transmission of Covid-19 in Indonesia. Jurnal Administrasi Kesehatan Indonesia, 8(2), 4. https://doi.org/10.20473/jaki.v8i2. 2020.4-14 